\title{
Proposal of public policies regarding the reduction of deforestation in Romania
}

\author{
Nezalizov Ana \\ Master of European Administration. Public institutions and policies (Faculty of Law and \\ Administrative Sciences - "Ovidius" University of Constanta, Romania) \\ ananezalizov18@gmail.com \\ Volume coordinators \\ Prof. univ. dr. habil. Mihaela Rus \\ "Ovidius" University of Constanta (Faculty of Law and Administrative Sciences) \\ psiholog_m@yahoo.com \\ Lect. univ. dr. Mihaela Sandu \\ "Ovidius" University of Constanta (Faculty of Psychology and Educational Sciences) \\ mihaela_naidin@yahoo.com \\ Asist. univ. dr. Tănase Tasențe \\ "Ovidius" University of Constanta (Faculty of Law and Administrative Sciences) \\ office@pluscommunication.eu
}

\begin{abstract}
This problem highlights the importance of reducing deforestation in order to improve the natural environment. The problem of clearing forests is not a novelty, but, on the contrary, the Romanian state has been facing this for a long time; It's worth mentioning that the problem of deforestation is not only at national level, but it is also felt globally. The massive deforestation is due to a high demand on the market, of the wood, but also of the wood products, most of them illegall, because poaching is at high levels in Romania. The general objective of this public policy is to stop illegalities regarding the forestry fund, to improve air quality and biodiversity and to stop illegal trade.
\end{abstract}

Keywords. public policy, deforestation, natural environment, poaching 
public policy - NGOs.

The nature of the In Romania, the problem of clearing forests is not a novelty, but, on the problem contrary, the Romanian state has been facing this for a long time with no improvement; We should mention that the problem of deforestation is not only at national level, but is also felt globally. The massive deforestation is due to a high demand on the market, of the wood, but also of the wood products, most of them illegal, because poaching is at high levels in Romania.

The issue of deforestation is not unique, but it still entails a lot of shortcomings, such as:

a) Desertification of the soil and decrease of its quality, which can be followed by water drying, landslides, etc .;

b) Decreased air quality due to $\mathrm{CO} 2$ emissions, which is constantly increasing;

c) Floods, which endanger the citizens who have their homes nearby;

d) Thus, biodiversity suffers, following the loss of shelter or climate change.

Following the studied and observed, we can say that the Romanian state is not sufficiently concerned in solving this problem, nor are quite rigorous measures taken against poaching, which might as well be considered a crime against nature and humanity, with disastrous effects in time. The measures taken by the state are not able to reach the desired effect, while poaching and other illegal activities are at an all-time high, resulting in disastrous consequences on the environment and on society as a whole.

We reached such a conclusion, because the problem is not a new one, and this is what we have been talking about for years, the state has not implemented real rules for combating deforestation, and the ones proposed have no visible effect, because the cuts continue and not only, they are becoming more and more bulky, especially poaching.

Legislative framework: Law 46 of March 19, 2008 Forestry Code (the normative act that includes, in systematic and unitary form, the norms of law regarding the administration, management, protection and guarding of the forestry fund, as well as the liability for the facts that affect the forest regime and forestry offenses. ). 


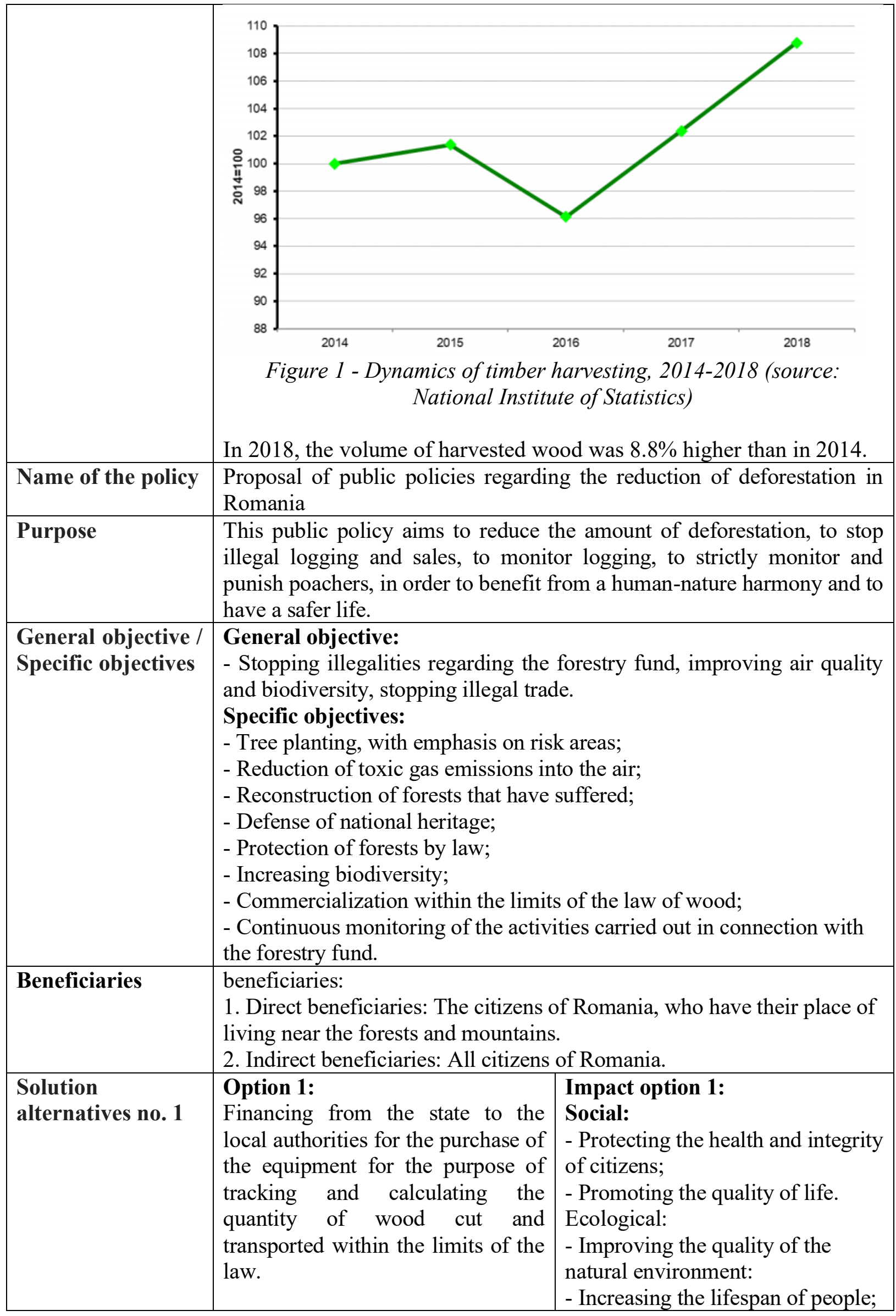




\begin{tabular}{|c|c|c|}
\hline & $\begin{array}{l}\text { Benefits: } \\
\text { 1. The authorities will be informed } \\
\text { about the quantity of wood } \\
\text { extracted; } \\
\text { 2. They will also benefit from } \\
\text { modern equipment to facilitate } \\
\text { work. } \\
\text { Risks: } \\
\text { 1. Lack of funds needed to } \\
\text { implement the policy. } \\
\text { 2. Including a financial stake, the } \\
\text { possible disinterest of both citizens } \\
\text { and the authorities. } \\
\text { Feasibility: High enough. }\end{array}$ & $\begin{array}{l}\text { - Soil fertility; } \\
\text { - Biodiversity; } \\
\text { - Plant protection; } \\
\text { - Reduction of toxic gas emissions. }\end{array}$ \\
\hline $\begin{array}{l}\text { Solution } \\
\text { alternatives no. } 2\end{array}$ & $\begin{array}{l}\text { Option 2: } \\
\text { Formation of certain groups of } \\
\text { people, both specialists and } \\
\text { volunteers to plant trees in areas } \\
\text { that have been subjected to } \\
\text { deforestation and beyond. } \\
\text { Benefits: } \\
\text { 1. The restoration of the forestry } \\
\text { fund, which brings with it a lot of } \\
\text { advantages for the whole society. } \\
\text { Risks: } \\
\text { 1. The state might not allocate } \\
\text { enough money for the training and } \\
\text { the reward of specialists involved } \\
\text { in those actions. } \\
\text { Feasibility: Pretty high. }\end{array}$ & $\begin{array}{l}\text { Impact option 2: } \\
\text { Social: } \\
\text { - Groups of people will have the } \\
\text { opportunity to interact and create a } \\
\text { pleasant working atmosphere; } \\
\text { - Promoting restored areas will be } \\
\text { easier to achieve. } \\
\text { Ecological: } \\
\text { - Conservation of the environment } \\
\text { and biodiversity; } \\
\text { - Beautifying the environment in } \\
\text { which we live; } \\
\text { - Increasing the forest fund; } \\
\text { - The quality of citizens' health. }\end{array}$ \\
\hline $\begin{array}{l}\text { The consultation } \\
\text { process }\end{array}$ & \multicolumn{2}{|c|}{$\begin{array}{l}\text { The consultation process will take place on several levels, as it has an } \\
\text { environmental, primarily social and budgetary impact. } \\
\text { 1. At the level of the ministries involved, which means a more in-depth } \\
\text { analysis of the proposed policy; } \\
\text { 2. At the level of the involved institutions such as local mayors, NGOs, } \\
\text { or even international actors, who will be willing to invest in this } \\
\text { project; } \\
\text { 3. At the level of the private environment: any company or firm } \\
\text { interested in contributing to the project support; } \\
\text { 4. At the level of society - citizens' consulate, in order to examine the } \\
\text { point of view of all the factors involved and to make a favorable } \\
\text { decision for everyone. }\end{array}$} \\
\hline
\end{tabular}


\begin{tabular}{l|l}
\hline Recommended & Solution 1 was recommended in favor of allocating funds to local
\end{tabular} solution authorities to purchase the necessary technical equipment to measure the quantity of timber transported and to improve control over the forest fund.

The main advantages are:

- Preventing the illegal sale of wood;

- Reforestation supported by NGOs;

- Restoration of the forest fund in the risk areas;

- Economic development of commercial companies within the limits of the law. 